Article

\title{
Does Industry Integration Improve the Competitiveness of China's Electronic Information Industry?-Evidence from the Integration of the Electronic Information Industry and Financial Industry
}

\author{
Weiliang Chen ${ }^{1,2, *}$, Xinjian Huang ${ }^{1,3}$, Yanhong Liu ${ }^{1}$ and Yan Song ${ }^{2}$ \\ 1 School of Management, Nanchang University, Nanchang 330031, China; hxjjgxy@126.com (X.H.); \\ liuyhncu@126.com (Y.L.) \\ 2 Department of City and Regional Planning, University of North Carolina at Chapel Hill, Chapel Hill, \\ NC 27517, USA; ys@email.unc.edu \\ 3 School of Economics and Management, Nanchang University, Nanchang 330031, China \\ * Correspondence: weiliang@email.unc.edu; Tel.: +1-(919)-593-5512
}

Received: 16 April 2019; Accepted: 8 May 2019; Published: 12 May 2019

check for updates

\begin{abstract}
As the pillar industry of China's national economy, the electronic information industry plays an important role in social development and has increasingly become an important indicator of international competitiveness in the informatization age. We constructed a fusion evaluation model of the electronic information industry and financial industry in China, and used coupling theory to measure the integration degree of the two industries. Next, we empirically measure the impact of the industrial integration level on the competitiveness of the electronic information industry. According to the empirical test, we found that (1) the coupling degree ranged from 0.9 to 1 with minimal changes and that a strong coupling relationship existed between the electronic information industry and financial industry; (2) the coupling coordination degree ranged between 0.59 and 0.80 , with a coordination level ranging from primary to intermediate coordination; and (3) the degree of industrial integration had a lagging positive impact on industrial competitiveness. Based on these results, we proposed policy recommendations to strengthen industrial integration and promote the international competitiveness of China's electronic information industry for various aspects such as government services, technology upgrades, industry integration, and effective capital entry.
\end{abstract}

Keywords: industrial integration; competitiveness; electronic information industry; financial industry; coupling coordination degree

\section{Introduction}

Since the reform and opening up of policy introduction in 1978, China's economy has engaged in the third scientific and technological revolution, which has grown rapidly to become the world's second largest economy [1]. China's success has occurred partially due to the establishment of a complete industrial system with a high degree of integration among the major industries [2]. Internet + , industry and city integration, and a sharing economy describe the epitomes of industrial integration. According to iResearch statistics, the scale of transactions in 10 industries, such as online entertainment and online education in China, reached 1146 billion CNY in 2017, a year-on-year growth rate of 49.6\%; the transaction scale of the internet consumer finance market exceeded 1000 billion CNY; and mobile payment transaction volume has exceeded 200,000 billion CNY, ranking first in the world [3]. From 2016 to 2017, the number of shared bicycles increased from 2 to 23 million and expanded to more than 
200 cities in China; the number of registered users has increased from 18.87 to 221.23 million, and the cumulative distance traveled increased from 2.51 billion to 29.95 billion kilometers [4]. Therefore, the great role of industry integration in economic development has been highly valuable to Chinese enterprises and the government.

China's electronic information industry has developed rapidly with huge demographic dividends. In 2017, the total revenue from the electronic information industry was 18,500 billion CNY, a year-on-year increase of $8.5 \%$; the fixed assets investment was 1300 billion CNY, which was a year-on-year increase of $25.3 \%$; the number of employees was 24.69 million, a year-on-year increase of $9.88 \%$ [5]; and the added value of the above-scale electronic information manufacturing industry increased by $13.8 \%$, and the total profit exceeded 700 billion CNY [6]. However, the development of the industry still faces many problems, such as low-end industries, lack of core competitiveness, and gradual loss of cheap labor [7]. The outbreak of incidents of the two Chinese technology giants (ZTE and Huawei) revealed the hidden struggles of China's electronic information industry [8]. When determining how to improve international competitiveness and attract high-quality capital to industrial development, the financial industry may play an important role $[9,10]$. As a green industry, the financial industry refers to special industries that operate financial products, including banking, insurance, trust, securities, and leasing [11]. The financial industry can provide financial services for the real economy, while making transaction methods more convenient and effectively controlling risks, thus improving the reform of corporate governance mechanisms. In 2017, the added value of China's financial industry exceeded 6,500 billion CNY, a year-on-year increase of 7.8\%; the number of employees was 6.89 million, a year-on-year increase of $3.55 \%$; and the total profit of the financial industry was 2860 billion CNY, a year-on-year increase of $9.01 \%$ [12]. Among them, commercial banks realized a net profit of 1750 billion CNY, a year-on-year increase of $6 \%$ [13].

Industrial integration is the trend in industrial development and would promote the optimization and upgrade of industrial structure [14]. The result of industrial integration is creating a new industrial form, to provide consumers with more humanized and more valuable products, and a more comfortable shopping experience through resource integration, technological innovation, and structural optimization functions, thereby enhancing the competitiveness of industries [15]. As a representative industry of industrial integration, the big data industry has experienced rapid development in recent years. The global big data market was 315 billion CNY in 2018. The market size will reach 560 billion CNY by 2022, with an average annual compound growth rate of $15.37 \%$ [16]. It is estimated that the size of China's big data market will reach 28 billion CNY in 2018, and the compound annual growth rate in the next five years is about $27.29 \%$ [16].

We believe that (1) sustainable development must be implemented in a specific economic operation mode, which must be based on industrial development. (2) The mode of industrial development is related to the effect of sustainable development. (3) The improvement of industrial competitiveness is an inherent requirement of sustainable development. The electronic information industry is the pillar industry in China, and the financial industry is an important lever to regulate the modern economy. Whether the integration of these two industries can promote the competitiveness of the electronic information industry was the focus of this study. The remainder of this article is structured as follows: Section 2 provides a literature review, Section 3 outlines the model construction and analysis, Section 4 discusses the influence of industrial integration on the competitiveness of the electronic information industry, and Section 5 includes our conclusions and recommendations.

\section{Literature Review}

The study of industrial integration originated from the observation of the phenomenon whereby the application of general technology spreads to different industries. Rosenberg [17] studied the industrial evolution of the American mechanical equipment industry from 1840 to 1910 and found that the widespread application of general machine manufacturing skills, such as drilling and grinding, in many industries enabled the independence of these general-purpose machines. The equipment industry and 
this process of independence is called technological convergence. With the wide application of digital technology in the field of information communication, the phenomenon of digital fusion convergence has attracted considerable attention. Yoffie [18] defined industrial integration as the integration of independent products after the adoption of digital technology. The European Commission reported that industrial integration is a fusion of three aspects: a technology network platform, market and industry alliance, and mergers [19]. Industrial integration was first formally proposed by Uekusa [20]. Legewie [21] thought that industrial integration stemmed from technological progress and the relaxation of regulations, which reduce the barriers between industries through technological innovation and strengthen the competition and cooperation between enterprises. Steiner [22] stated that industrial integration was a new type of industry, due to the development of information technology, which has changed the characteristics of the original industrial products and market demand, resulting in a change in the competition and cooperation between enterprises in the industry. Uson et al. [23] thought that industrial integration was a phenomenon in which the established economic activity of an industry crossed that of another industry when an industrial boundary was established in the real economy. The expressions of industrial integration are diverse, but basically refer to the economic phenomenon where the industrial boundaries of different industries have blurred due to mutual integration, mutual intersection and mutual penetration.

To measure industrial integration, James and Jun [24] used the change data of the network structure to analyze the convergence of the information industry. Empirical studies showed that changes in industrial structure can identify the existence and degree of integration of enterprise integration. Alfonso and Salvatore [25] used the Herfindahl-Hirschman Index (HHI) to study the technical integration of the electronic information industry. Helleno et al. [26] also used the HHI to measure the integration degree of the electronic information industry and manufacturing technology. Jiang et al. [27] used a hierarchical model of informatization and industrialization to analyze the status of Wenzhou's industrial low-voltage electric clusters, and proposed policy recommendations for promoting the integration of informatization and industrialization in Wenzhou. Throsby [28] used the Computable General Equilibrium (CGE) model and input-output method to study the way industry integration works and its impact on the economy and society. Cao [29] constructed an informatization and industrialization integration index evaluation model to evaluate integration from the aspects of integration environment, integration breadth, and integration benefit. Many scholars applied coupling theory to industrial integration. Weick [30] used coupling theory to study social and economic problems. Chen [31] analyzed the dynamic coupling evolution mechanism, dynamic coupling process, and evolution trend of strategic emerging industries and traditional industries. Su et al. [32] analyzed the working condition of the coupling mechanism in the Chinese shipbuilding industry cluster, thus providing analysis of the then-current development of the shipbuilding industry. They found that the coupling degree of China's strategic emerging industries and traditional industries changed little, which were moderately coupled. Kim et al. [33] used a large amount of unstructured data to analyze the trend in and model the industrial integration in the United States, and found that the integration model tended to be stable when industrial clusters slowly integrated.

In terms of the impact of industrial integration on industrial development, Dosi [34] analyzed the role of finance in innovation and industrial integration, and studied the one-way relationship between the two. Rajiv et al. [35] proposed that enterprises' application of electronic technology was conducive to reducing costs, and that industrial integration had a positive correlation with industrial performance. Colombo and Grilli [36] empirically researched the relationship between financial institution loans and high-tech enterprises using 386 high-tech enterprises in Italy. The results showed that financial institution loans had a key role in promoting the development of high-tech enterprises. Englmaier and Reisinger [37] proposed strengthening the use of information industry resources in the process of manufacturing development, which is conducive to improving the production efficiency and industrial performance of the manufacturing industry. Saviotti and Pyka [38] developed Nelson's [39] theory of co-evolution of technology and institutions, and incorporated technology and financial systems 
into the framework of collaborative evolution analysis, and described the co-evolutionary conditions and processes of technology and financial systems through the economic development model created by the new industry sector. Colombo et al. [40] found that information technology has not improved the performance of the manufacturing industry because the level of informatization is low, and a certain lag exists in the effect of industrial integration on the improvement of industrial performance. Forero [41] stated that information technology could significantly improve technical efficiency and help companies gain a competitive advantage. Brock et al. [42] found that when spatial externalities were not internalized by enterprises, industrial integration may occur endogenously in a competitive equilibrium, and that the externalities of information technology had a positive impact on total factor productivity (TFP). Anderson and Toffolo [43] studied the integration of sawmills with pellet plants and combined heat and power (CHP) plants, and found that the two plants could save up to $18 \%$ of the sawmill biomass by-products through technology integration, which had a positive impact on improving plant performance. Industrial integration provides considerable development impetus in industries. Oltean et al. [44] thought that information technology could improve corporate performance. Lozada [45] suggested that the integration and development of traditional industries and the Internet of Things industry could accelerate the differentiation and reorganization of traditional industries, and that the vertical integration of industries could stimulate the vitality of traditional industries. Nathan [46] proposed that the coupling degree and coupling coordination degree between China's information industry and manufacturing industry have a positive correlation with the optimization and upgrading of industrial structure.

Through the literature review, we learned that the phenomenon of industrial integration begins with the diffusion of general technology among industries. With the development of digital and information technology, the industrial integration caused by technology is so obvious that technological innovation is considered by the early industrial integration research to be the core factor that causes the integration between industries. The first to integrate with the electronic information industry was the traditional manufacturing industry. At present, most of the research results have mainly concentrated on the analysis of the integration of the industry and the electronic information industry. However, the integration of the electronic information industry and other non-manufacturing industries is increasingly being studied and the integration of the electronic information industry and emerging industries has begun to enter the field of research. For example, in the integration of the electronic information industry and financial industry, the translation of breakthrough of economic research to action should be a research direction of industrial integration. In terms of research methods, the HHI, correlation coefficient method, and input-output method were used to measure the degree of coupling coordination between industries. For the impact of the industrial integration on industrial development, some researchers reported that industrial integration has a positive impact on industrial competitiveness, whereas others thought there is no significant impact. In this paper, we analyzed the integration of the two major industries by first measuring the coupling degree of the electronic information industry and the financial industry. Then used the entropy method and vector auto-regression model (VAR) to analyze the impact of industry integration on the competitiveness of the Chinese electronic information industry. Finally, on this basis, we provide systematic policy recommendations for improving the competitiveness of China's electronic information industry. In short, we expanded the boundaries of industrial integration research. Empirical research on industrial integration mostly focused on the integration of manufacturing and manufacturing in the past, while the integration of manufacturing and service industries was more biased towards qualitative research. But now, we use empirical methods to study the integration of the electronic information industry and financial industry. In addition, we broke through the evaluation system of single competitiveness. Previous studies have been compared in similar industries to derive relevant indices of industrial competitiveness. We study industrial competitiveness from the perspective of industrial integration, and no longer judge the competitiveness from individual or multiple industry indicators. This will help to improve the competitiveness of the industry from the perspective of industrial synergy development. 


\section{Model Constructions and Analysis}

Three main methods are available to estimate industrial integration: index measurement algorithm, correlation coefficient between industries, and the input-output method. Felicia and Nicholas [47] selected 32 companies between 1930 and 1990, and used the correlation coefficient of inter-industry patents to measure the degree of integration between industries. Pichler et al. [48] used the input-output method to measure the degree of European financial integration, then studied the impact of the financial integration process on the European economy. Yuan [49] used the industrial coupling coordination degree index to study the level of integration between China's environmental protection industry and the rubber manufacturing industry. Hagedoorn and Schakenraad [50] chose Europe as the research object and empirically found that the electronic information and textile industries had a good state of coordination. The patent data for the index method and the patent coefficient method, which both show the technical integration between enterprises, can be difficult to obtain, and the input-output method has limitations in the assumption, preparation, and optimization of the model. Therefore, we used the degree of coupling coordination to estimate and evaluate the level of industrial integration.

\subsection{Coupling Model}

\subsubsection{Coupling Concept}

The concept of coupling originated from the field of physics, appearing in communication engineering and software engineering as coupling capacitors and system coupling. In physics, coupling refers to the interaction and mutual influence between two or more systems [51]. From the perspective of synergy, the order and structure of the system, when reaching the critical region, depend on the coupling between multiple subsystems in the system and their coordination degree [52]. The concept of "coupling" has been extended to many fields of social science. Many scholars refer to the objective things that combine two or more social phenomena to function as coupling and use the coupling model in physics to quantitatively analyze the degree of coupling coordination. In this paper, the two subsystems that connect and promote each other in the electronic information industry and financial industry were defined as the "electronic information industry-financial industry" coupling system. The coupling degree model and coupling coordination degree model were used to measure the level of integration between the two industries.

\subsubsection{Power Function}

The variable $U_{i}(i=1,2)$ represents the comprehensive order parameter of the coupling system of the electronic information industry and financial industry development, and $X_{i j}$ represents the index value of the $j$ th index $U_{i j}$ of the $i$ th order parameter. When the system tends to stabilize the critical point, the upper and lower limits of each order parameter are represented by $\alpha_{i j}$, and $\beta_{i j}$ [53]. Then the power function is expressed as Equations (1) and (2):

$$
\begin{gathered}
X^{\prime}{ }_{\mathrm{ij}}=\frac{X_{\mathrm{ij}}-\beta_{\mathrm{ij}}}{\alpha_{\mathrm{ij}}-\beta_{\mathrm{ij}}} \quad U_{\mathrm{ij}} \text { is the positive ef ficacy index } \\
X_{\mathrm{ij}}^{\prime}=\frac{\alpha_{\mathrm{ij}}-X_{\mathrm{ij}}}{\alpha_{\mathrm{ij}}-\beta_{\mathrm{ij}}} \quad U_{\mathrm{ij}} \text { is the negative ef ficacy index }
\end{gathered}
$$

where $X_{i j}^{\prime}$ is the magnitude of the function of the variable to the $X_{i j}$ system, and the value is between 0 and 1 . When the value is closer to 1 , the contribution to the system is larger. 


\subsubsection{Calculation of Coupling Coordination}

We established a coupled system model including the development of the electronic information industry and financial industry using linear weighting method to calculate the contribution of each subsystem to the order of the total system [54]:

$$
\mathrm{Ui}=\sum_{j=1}^{n} X^{\prime}{ }_{i j} \lambda_{i j}, \sum_{j=1}^{m} \lambda_{i j}=1
$$

where $\lambda_{i j}$ is weight of each indicator. Using the concept of information entropy to determine the weight, the $j$ th indicator of the $i$ th order parameter is:

$$
P i j=\frac{X_{i j}}{\sum_{i=1}^{m} X_{i j}}
$$

The total contribution of each program to attribute $X_{j}$ is:

$$
\mathrm{Ej}=-\sum_{\mathrm{i}=1}^{\mathrm{m}} \mathrm{P}_{\mathrm{ij}} \ln \left(\mathrm{P}_{\mathrm{ij}}\right) / \operatorname{lnm}
$$

Then, the weight of each attribute is $\lambda_{i j}$ and $\mathrm{d}_{\mathrm{j}}=1-\mathrm{E}_{\mathrm{j}} ; \sum_{\mathrm{j}=1}^{\mathrm{n}} \lambda_{i j}=1$, as per

$$
\lambda_{i j}=\frac{\mathrm{d}_{\mathrm{j}}}{\sum_{\mathrm{j}=1}^{\mathrm{n}} \mathrm{d}_{\mathrm{j}}}
$$

where $C$ is set as the degree of coupling between the electronic information industry and the financial industry. The coupling system of the electronic information industry and financial industry is composed of $k$ subsystems, and its specific coupling degree is:

$$
C_{k}=\left\{\frac{\mathrm{U}_{1} \mathrm{U}_{2} \ldots \mathrm{U}_{\mathrm{k}}}{\prod_{\mathrm{i}, \mathrm{j}=1, \mathrm{i} \neq \mathrm{j}}\left(\mathrm{U}_{\mathrm{i}}+\mathrm{U}_{\mathrm{j}}\right)}\right\} / \mathrm{k}
$$

Then, the model of the coupling degree between the electronic information industry and financial industry can be defined as:

$$
C=\left\{\frac{\mathrm{U}_{1} \mathrm{U}_{2}}{\left(\mathrm{U}_{1}+\mathrm{U}_{2}\right)\left(\mathrm{U}_{1}+\mathrm{U}_{2}\right)}\right\} / 2
$$

The coupling value $C$ is between 0 and 1 . The larger the $C$, the higher the degree of coordination between the electronic information industry and financial industry, and vice versa. Equation (4) shows that when $C=0$, the correlation between the electronic information industry and the financial industry system is extremely low and in a completely uncoupled phase; when $0<C \leq 0.3$, the two systems are in a low level coupling stage, the electronic information industry is still very weak, and the financial industry is also lagging; when $0.3<C \leq 0.5$, the two systems are in a Stationary stage, and the electronic information industry has already reached a certain scale. The impact on the financial industry begins to appear, and the development of the electronic information industry has improved; When $0.5<C \leq 0.8$, the two systems are in the running-in phase, the electronic information industry and financial industry have all rapidly improved, and the system enters a period of rapid development; when $0.8<C<1$, the two systems are in a high-level coupling phase; and when $C=1$, a benign resonant coupling between the two systems leads to a new ordered structure as shown in Table 1 [55]. 
Table 1. Standards for the coordination of industry.

\begin{tabular}{ccccccc}
\hline Coupling $(C)$ & $C=0$ & $0<C \leq 0.3$ & $0.3<C \leq 0.5$ & $0.5<C \leq 0.8$ & $0.8<C<1$ & $C=1$ \\
\hline Coupling phase & Uncoupled & Low level & $\begin{array}{c}\text { Rival each } \\
\text { other }\end{array}$ & Run-in & High level & $\begin{array}{c}\text { Benign } \\
\text { resonance }\end{array}$ \\
\hline
\end{tabular}

Since coupling is composed of two aspects, coordination and development, although the scores of the two subsystems' comprehensive order parameters $U_{1}$ and $U_{2}$ are relatively low, the degree of coupling between them is higher when the scores of the two are inconsistent. It is possible to be misled by relying solely on the degree of coupling, so the degree of coupling must be measured from these two aspects. Therefore, we further constructed a model that could reflect the degree of mutual coupling, and simultaneously effectively measure the coupling degree of the electronic information industry and financial industry and the degree of contribution to the system. To fulfill the above requirements, the calculation method of the system coupling degree was revised, and the coupling degree model of the electronic information industry-financial industry system was constructed. The algorithm can be expressed as:

$$
D=\sqrt{C \times T}
$$

where $C$ is the degree of coupling, $D$ is the degree of coupling coordination, and $T$ is the comprehensive evaluation index of the development of the electronic information industry and the financial industry, which reflects the overall level of synergy between the two. $T=a \times U_{1}+b \times U_{2}, a+b=1$, where $a$ and $b$ represent the contribution coefficient of the development of the electronic information industry and financial industry, respectively. The values of $a$ and $b$ are to be determined.

To distinguish the degree of coupling and coordination between the electronic information industry and financial industry, it is necessary to classify the degree of coupling coordination. The representative of the coupling coordination degree evaluation standard is the classification standard created by Tanaka [56], as shown in Table 2.

Table 2. Evaluation criteria for coupling coordination.

\begin{tabular}{cccccc}
\hline $\begin{array}{c}\text { Coupling } \\
\text { Coordination }\end{array}$ & {$[\mathbf{0 , 0 . 1 )}$} & {$[\mathbf{0 . 1 , 0 . 2 )}$} & {$[\mathbf{0 . 2 , 0 . 3 )}$} & {$[\mathbf{0 . 3 , 0 . 4 )}$} & {$[\mathbf{0 . 4 , 0 . 5 )}$} \\
\hline $\begin{array}{c}\text { Coordination } \\
\text { level }\end{array}$ & $\begin{array}{c}\text { Extreme } \\
\text { disorder }\end{array}$ & $\begin{array}{c}\text { Serious } \\
\text { disorder }\end{array}$ & $\begin{array}{c}\text { Moderate } \\
\text { disorder }\end{array}$ & Mild disorder & $\begin{array}{c}\text { On the verge of } \\
\text { disorder }\end{array}$ \\
\hline $\begin{array}{c}\text { Coupling } \\
\text { Coordination }\end{array}$ & {$[\mathbf{0 . 5 , 0 . 6 )}$} & {$[\mathbf{0 . 6 , 0 . 7 )}$} & {$[\mathbf{0 . 7 , 0 . 8 )}$} & {$[\mathbf{0 . 8 , 0 . 9 )}$} & {$[\mathbf{0 . 9 , 1 ]}$} \\
\hline $\begin{array}{c}\text { Coordination } \\
\text { level }\end{array}$ & Low & $\begin{array}{c}\text { Primary } \\
\text { coordination }\end{array}$ & $\begin{array}{c}\text { Intermediate } \\
\text { coordination }\end{array}$ & $\begin{array}{c}\text { Good } \\
\text { coordination }\end{array}$ & $\begin{array}{c}\text { Quality } \\
\text { coordination }\end{array}$ \\
\hline
\end{tabular}

\subsection{Indicator Selection and Weight}

According to the coupling and interaction between the electronic information industry and the financial industry, to fully determine the degree of coupling coordination, we constructed a first-level indicator system of two subsystems from three aspects: scale, growth, and efficiency, and each level was set up under the first level indicator [57]. Scale refers to the size of the output or size of the operation of industry, growth is the ability to expand the operations of an industry, and efficiency reflects the productivity level of an industry [58]. The scale indicator includes the industry added value, increase in value as a percentage of gross domestic product (GDP), and total industrial assets. The growth indicator includes the industrial total asset growth rate, industrial employment growth rate, and industrial fixed assets investment growth rate. The efficiency indicator includes the industrial return on equity, industry net profit growth rate, and industrial employment contribution rate. Three secondary indicators and the specific evaluation index systems are shown in Table 3. 
Table 3. Coupling and coordinated evaluation index system.

\begin{tabular}{|c|c|c|c|c|c|}
\hline Subsystem & $\begin{array}{l}\text { Primary } \\
\text { Indicator }\end{array}$ & Weights & Secondary Indicator & Unit & Weights \\
\hline \multirow{7}{*}{$\begin{array}{c}\text { Financial } \\
\text { industry } \\
\text { subsystem }(X)\end{array}$} & \multirow{2}{*}{$\begin{array}{c}\text { Scale } \\
\text { indicator }\left(X_{1}\right)\end{array}$} & \multirow{2}{*}{0.3537} & Industry added value $\left(\mathrm{X}_{11}\right)$ & Billion Yuan & 0.1231 \\
\hline & & & Total industrial assets $\left(\mathrm{X}_{13}\right)$ & Billion Yuan & 0.1274 \\
\hline & \multirow{2}{*}{$\begin{array}{c}\text { Growth } \\
\text { indicator }\left(\mathrm{X}_{2}\right)\end{array}$} & \multirow[b]{2}{*}{0.3508} & Industrial total asset growth rate $\left(\mathrm{X}_{21}\right)$ & $\%$ & 0.0597 \\
\hline & & & Industrial employment growth rate $\left(\mathrm{X}_{22}\right)$ & $\%$ & 0.1951 \\
\hline & \multirow{3}{*}{$\begin{array}{c}\text { Efficiency } \\
\text { indicator }\left(X_{3}\right)\end{array}$} & \multirow{3}{*}{0.2955} & Industrial return on equity $\left(X_{31}\right)$ & $\%$ & 0.0631 \\
\hline & & & Industry net profit growth rate $\left(X_{32}\right)$ & $\%$ & 0.1273 \\
\hline & & & Industrial employment contribution rate $\left(\mathrm{X}_{33}\right)$ & $\%$ & 0.1051 \\
\hline \multirow{6}{*}{$\begin{array}{c}\text { Electronic } \\
\text { information } \\
\text { industry } \\
\text { subsystem }(\mathrm{Y})\end{array}$} & \multirow{2}{*}{$\begin{array}{c}\text { Scale } \\
\text { indicator }\left(\mathrm{Y}_{1}\right)\end{array}$} & \multirow[b]{2}{*}{0.2495} & Industry added value $\left(\mathrm{Y}_{11}\right)$ & Billion Yuan & 0.0988 \\
\hline & & & Increase in value as a percentage of GDP $\left(\mathrm{Y}_{12}\right)$ & $\%$ & 0.0875 \\
\hline & $\begin{array}{c}\text { Growth } \\
\text { indicator }\left(\mathrm{Y}_{2}\right)\end{array}$ & 0.4547 & Industrial fixed assets investment growth rate $\left(\mathrm{Y}_{23}\right)$ & $\%$ & 0.1047 \\
\hline & \multirow{3}{*}{$\begin{array}{c}\text { Efficiency } \\
\text { indicator }\left(\mathrm{Y}_{3}\right)\end{array}$} & \multirow{3}{*}{0.2958} & Industrial return on equity $\left(\mathrm{Y}_{31}\right)$ & $\%$ & 0.0359 \\
\hline & & & Industry net profit growth rate $\left(\mathrm{Y}_{32}\right)$ & $\%$ & 0.1879 \\
\hline & & & Industrial employment contribution rate $\left(\mathrm{Y}_{33}\right)$ & $\%$ & 0.0720 \\
\hline
\end{tabular}

In the financial industry subsystem, the scale indicator has a weight of 0.3537 , of which industry added value, increase in value as a percentage of GDP, and total industrial assets have weights of $0.1231,0.1032$, and 0.1274 , respectively; the growth indicator has a weight of 0.3508 , of which industrial total asset growth rate, industrial employment growth rate, and industrial fixed assets investment growth rate have weights of $0.0597,0.1951$, and 0.0960 , respectively; and the efficiency index has a weight of 0.2955 , of which industrial return on equity, industrial net profit growth rate, and industrial employment contribution rate have weights of $0.0631,0.1273$, and 0.1051 , respectively. In the electronic information industry subsystem, the scale indicator has a weight of 0.2495 , of which industry added value, increase in value as a percentage of GDP, and total industrial assets have weights of 0.0988 , 0.0875 , and 0.0632 , respectively; the growth indicator has a weight of 0.4547 , of which industrial total asset growth rate, industrial employment growth rate, and industrial fixed assets investment growth rate have weights of $0.1789,0.1711$, and 0.1047 , respectively; the efficiency index has a weight of 0.2958 , of which industrial return on equity, industrial net profit growth rate, and industrial employment contribution rate have weights of $0.0559,0.1879$, and 0.0720 , respectively.

The data in this study were obtained from the China Statistical Yearbook [59], China Electronic Information Industry Statistical Yearbook [5], China Financial Yearbook [12], and China's economic and social big data platform [60].

\subsection{Estimation of Industrial Integration Level}

According to the evaluation model of the industrial integration level constructed above, the weight of each specific index in the index system was first calculated using the entropy method, as shown in Table 3. Then, the annual electronic information was estimated based on the estimation method of the coupling degree and coupling coordination degree. The industrial comprehensive contribution value is $U$, financial industry comprehensive contribution value is $G$, coupling correlation degree is $\mathrm{C}$, and the coupling coordination degree is D. Finally, according to the coupling coordination degree classification standard in Table 2, we determined the annual coordination degree of the electronic information industry and the financial industry, as shown in Table 4. From 2008 to 2017, the average added value of the financial industry in GDP was $7.01 \%$, and the average added value of the electronic information industry was $3.50 \%$. The added value of the financial industry was about twice that of the electronic information industry. Assuming that only the financial industry and the electronic information industry exist in the economic system, the contribution ratio of the financial industry is $2 / 3$, and the contribution ratio of the electronic information industry is $1 / 3$ [61]. So, the contribution 
coefficient $a$ of the electronic information industry is $1 / 3$, and the contribution coefficient $b$ of the financial industry is $2 / 3$.

Table 4. Coordination degree of the electronic information industry and the financial industry.

\begin{tabular}{cccccc}
\hline Year & $\begin{array}{c}\text { Financial Industry } \\
\text { Comprehensive } \\
\text { Contribution } \\
\text { Value U }\end{array}$ & $\begin{array}{c}\text { Electronic } \\
\text { Information Industry } \\
\text { Comprehensive } \\
\text { Contribution Value G }\end{array}$ & $\begin{array}{c}\text { Coupling } \\
\text { Degree C }\end{array}$ & $\begin{array}{c}\text { Coupling } \\
\text { Coordination } \\
\text { Degree D }\end{array}$ & Coordination Level \\
\hline 2017 & 0.6803 & 0.5139 & 0.9902 & 0.7866 & Intermediate coordination \\
2016 & 0.6782 & 0.5052 & 0.9893 & 0.7835 & Intermediate coordination \\
2015 & 0.6575 & 0.6189 & 0.9995 & 0.8027 & Good coordination \\
2014 & 0.6016 & 0.6343 & 0.9996 & 0.7825 & Intermediate coordination \\
2013 & 0.5340 & 0.6196 & 0.9972 & 0.7490 & Intermediate coordination \\
2012 & 0.4778 & 0.5891 & 0.9945 & 0.7156 & Intermediate coordination \\
2011 & 0.3744 & 0.5380 & 0.9838 & 0.6496 & Primary coordination \\
2010 & 0.3316 & 0.4523 & 0.9881 & 0.6061 & Primary coordination \\
2009 & 0.3225 & 0.4073 & 0.9932 & 0.5902 & Reluctant coordination \\
2008 & 0.4793 & 0.3514 & 0.9881 & 0.6569 & Primary coordination \\
\hline
\end{tabular}

From the perspective of the coupling degree, the coupling degree between China's electronic information industry and financial industry ranged from 0.9 and 1 with a minimal change. This shows that there was a strong coupling relationship between the two industries. There was a strong correlation between the subsystems of these two industries, which promotes benign interactive development. From the perspective of coupling coordination degree, the electronic information industry and the financial industry were basically in a state of volatility, with coordination ranging from primary coordination to the intermediate level, and the coupling relationship between the two was strong. The main reason for the decline in coordination level in 2009 was the impact of the 2008 financial crisis. The coordination degree after 2011 exceeded the level before the financial crisis, and reached a good coordination state in 2015, and has remained stable since then.

\section{Influence of Industrial Integration on Competitiveness of the Electronic Information Industry}

Analysis of the influencing factors in Porter's diamond model on industrial competitiveness can be used to describe the changes in the competitiveness of the electronic information industry by production scale, production efficiency, innovation ability, and export scale [62,63]. The four are reflected by total sales revenue, total labor productivity, total patents, and total exports, respectively. The total sales revenue reflects the total scale of the production activities of the enterprise. The total labor productivity is the industrial added value divided by the average number of all employees in the same period. The total number of patents reflects the ability of technological innovation and the total export value reflects the international competitiveness of the industry.

\subsection{Estimation of Competitiveness of the Electronic Information Industry}

To reflect the comprehensive competitiveness of the electronic information industry better, we used the improved entropy method to weight each index. The improved entropy method is a more objective assignment method that helps to weaken the influence of extreme values on the evaluation results. The calculation of the improved entropy method is as follows.

Computational comprehensive evaluation index:

$$
Z_{i}=\sum_{j=1}^{n} Z_{i j} \lambda_{i j}
$$

where $Z_{i}$ is the comprehensive evaluation value of the $i$-th scheme. 
The data were obtained from the China Electronic Information Statistics Yearbook (2008-2017) [5]. Based on the improved entropy method, we quantitative analyzed China's electronic information industry competitiveness. Figure 1 shows that the competitiveness score of the electronic information industry has demonstrated a continuous uptrend, which indicates that the competitiveness of China's electronic information industry has continued to strengthen. Among them, the lowest score was in 2009 and the highest score was in 2017. The decline of the industrial competitiveness score in 2009 was mainly due to the lagging effect of the global financial crisis in 2008. After 2011, the competitiveness score exceeded that of 2008, which indicates that China's electronic information industry has recovered to the level before the financial crisis, accelerated development in the next subsequent years, and its competitiveness has been significantly improved.

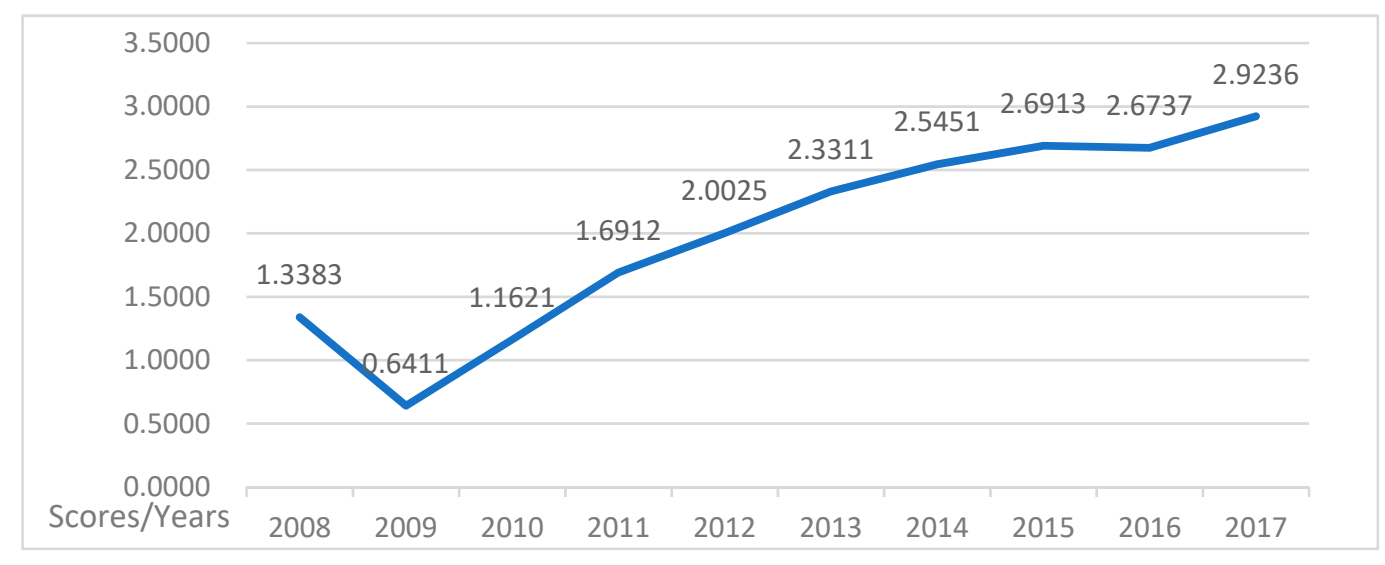

Figure 1. Trends in the competitiveness of China's electronic information industry.

4.2. Direction and Extent of Industrial Integration Affecting Competitiveness of the Electronic Information Industry

The measured degree of integration and the industrial competitiveness index were tested for stationarity. If the data were stable, the vector auto-regression model and Granger causality relation test were performed.

\subsubsection{Model Construction}

The VAR is an econometric model proposed by Sims in 1980 [64] and is constructed according to the statistical properties of the data. The VAR model constructs the model by using each endogenous variable as a function of the hysteresis value of all endogenous variables in the system, thereby extending the univariate auto-regression model to a vector auto-regression model consisting of multiple time series variables. The mathematical expression of VAR is

$$
y_{t}=\Phi_{1} y_{t-1}+\ldots+\Phi_{p} y_{t-p}+\varepsilon_{t} \quad t=1,2, \ldots, T
$$

where $y_{t}$ is a $k$-dimensional endogenous variable column vector, $p$ is the lag order, $T$ is the number of samples, $\Phi_{1}, \ldots \ldots ., \Phi_{\mathrm{p}}$ is the $\mathrm{k} \times \mathrm{k}$-dimensional coefficient matrix to be estimated, and $\varepsilon_{t}$ is the $k$ -dimensional perturbed column vector.

The mathematical vector expression of VAR is written as (12):

$$
\left\{\begin{array}{c}
y_{1 t} \\
y_{2 t} \\
\ldots \\
y_{k t}
\end{array}\right\}=\Phi_{1}\left\{\begin{array}{c}
y_{1 t-1} \\
y_{2 t-1} \\
\ldots \\
y_{k t-1}
\end{array}\right\}+\ldots+\Phi_{p}\left\{\begin{array}{c}
y_{1 t-p} \\
y_{2 t-p} \\
\ldots \\
y_{k t-p}
\end{array}\right\}+\left\{\begin{array}{c}
\varepsilon_{1 t} \\
\varepsilon_{2 t} \\
\ldots \\
\varepsilon_{k t}
\end{array}\right\} t=1,2, \ldots, T
$$




\subsubsection{Index Data Stability Test}

Due to sensitivities in the response of the lag period, it is necessary to select an appropriate lag period before using VAR for analysis. When determining the optimal lag order of the model, ensure that the lag order is large enough but not too large, otherwise the degree of freedom of the model will decrease. In general, the usual method for choosing the lag period is the minimum criterion for the Akaike criterion (AIC) and Schwartz criterion (SC) values.

When the lag period was 2, the values of AIC and SC were the smallest, and at this time, final prediction error (FPE), AIC, SC, and Hannan-Quinn criterion (HQ) all passed the test (marked with * in Table 5). Therefore, the lag period is was set as 2 in this paper.

Table 5. Information values under different lag periods.

\begin{tabular}{ccccccc}
\hline Lag & LogL & $\begin{array}{c}\text { Likelihood } \\
\text { Ratio (LR) }\end{array}$ & $\begin{array}{c}\text { Final } \\
\text { Prediction } \\
\text { Error (FPE) }\end{array}$ & $\begin{array}{c}\text { Akaike } \\
\text { Criterion } \\
\text { (AIC) }\end{array}$ & $\begin{array}{c}\text { Schwartz } \\
\text { Criterion (SC) }\end{array}$ & $\begin{array}{c}\text { Hannan-Quinn } \\
\text { Criterion (HQ) }\end{array}$ \\
\hline 0 & 15.87312 & NA & 0.000107 & -3.468279 & -3.448418 & -3.602229 \\
1 & 33.77550 & $22.37798^{*}$ & $6.37 \times 10^{-6}$ & -6.720155 & -6.620853 & -7.345727 \\
2 & 36.88062 & 2.328839 & $3.57 \times 10^{-6 *}$ & $-6.943876^{*}$ & $-6.884295 *$ & $-7.389907 *$ \\
\hline \multicolumn{7}{r}{ * indicates lag order selected by the criterion. }
\end{tabular}

To prevent false regression or pseudo-regression, the stability of the variable data needs to be checked before VAR and the Granger causality relation test. We selected the unit root test to conduct a stationarity test on industrial competitiveness (IC) and industrial integration degree (IID). The unit root test results of IC in the lag period of 2 showed that, under the three significance levels of $1 \%, 5 \%$, and $10 \%$, the critical values of the unit root test were $-4.803492,-3.413313$, and -2.841819 , respectively. The t-statistic was smaller than the corresponding critical value, so IC was stable at the $1 \%, 5 \%$, and $10 \%$ significance levels. Similarly, IDD was stable at the $1 \%, 5 \%$, and $10 \%$ significance level, as shown in Table 6.

Table 6. Unit root test results for industrial competitiveness (IC) and industrial integration degree (IID).

\begin{tabular}{ccccc}
\hline $\begin{array}{c}\text { Augmented } \\
\text { Dickey-Fuller Test }\end{array}$ & Lag & $\boldsymbol{t}$-Statistic & Level & Critical Values \\
\hline \multirow{2}{*}{ IC } & 2 & -6.998889 & $1 \%$ & -4.803492 \\
& & & $10 \%$ & -3.403313 \\
& \multirow{2}{*}{2} & & $1 \%$ & -2.841819 \\
\hline \multirow{2}{*}{ IID } & & & $5 \%$ & -2.937216 \\
& & & $10 \%$ & -1.598068 \\
\hline
\end{tabular}

\subsubsection{VAR Analysis}

The IDD and IC models were established by Eviews software with a lag period of 2 and a constant $C$ model. The results are provided in Table 7. 
Table 7. Vector auto-regression (VAR) results.

\begin{tabular}{ccc}
\hline & IC & IID \\
\hline & 1.073264 & 0.076440 \\
IC $(-1)$ & $(0.36226)$ & $(0.04650)$ \\
& $(2.96269)$ & $(1.64375)$ \\
\hline & 0.028628 & 0.039750 \\
IC (-2) & $(0.37711)$ & $(0.04841)$ \\
& $(0.07592)$ & $(0.82112)$ \\
\hline & 0.125433 & 0.233612 \\
IID $(-1)$ & $(2.44574)$ & $(0.57070)$ \\
& $(-0.71150)$ & $(0.40934)$ \\
\hline & 0.369962 & -0.481170 \\
IID $(-2)$ & $(2.52018)$ & $(0.32351)$ \\
& $(0.14680)$ & $(-1.48732)$ \\
\hline & 2.078403 & 0.680638 \\
C & $(2.54663)$ & $(0.32691)$ \\
& $(0.81614)$ & $(2.08204)$ \\
\hline
\end{tabular}

As can be seen from the above table, the regression equation of IID and IC is IC $=0.125433 \times$ IID $(-1)+0.369962 \times \operatorname{IID}(-2)+2.078403$. When other conditions remain unchanged, if the IID rises by 1 unit, the IC will rise by 0.125433 in lag phase 1 and 0.369962 in lag phase 2.

\subsubsection{Granger Causality Relation Test}

According to the stationarity test and VAR, the impact of the integration of China's electronic information industry and financial industry on the competitiveness of electronic information industry is significant. At this point, a Granger causality relation test of IID and IC was needed to determine whether these two variables are Granger causes of each other. The test results are shown in Table 8.

Table 8. Granger causality relation test of IID and IC.

\begin{tabular}{cccc}
\hline Null Hypothesis & Lag Period & F-Statistic & Probability \\
\hline IID does not Granger Cause IC & \multirow{2}{*}{0} & 12.5643 & 0.0298 \\
IC does not Granger Cause IID & & 3.65229 & 0.1732 \\
\hline IID does not Granger Cause IC & \multirow{2}{*}{1} & 9.36708 & 0.1023 \\
IC does not Granger Cause IID & & 0.15685 & 0.8771 \\
\hline IID does not Granger Cause IC & \multirow{2}{*}{2} & 2.84301 & 0.0241 \\
IC does not Granger Cause IID & & 0.53377 & 0.7658 \\
\hline
\end{tabular}

According to the test results, when the lag period was 0,1 , and 2, the original hypothesis that IID does not Granger cause IC was not established, so the industrial integration degree is the Granger cause of industrial competitiveness. When the lag period was $0,1,2$, the original hypothesis that IC does not Granger cause IID was established, so industrial competitiveness is not the Granger cause of industrial integration. In summary, there is a unilateral causal relationship between industrial integration and industrial competitiveness. In other words, industrial integration is the Granger cause for industrial competitiveness.

\section{Conclusions and Recommendations}

Sustainable development is a concept with a sustainable approach and development. It refers to the development model that meets the needs of the present generation under the conditions of protecting the environment and is forward-looking without damaging the needs of future generations. 
Sustainable development must be implemented in a specific economic operation model, which is based on industrial development. Therefore, the mode of industrial development is related to the effect of sustainable development. There are three questions that must be answered to achieve sustainable development. What are the inherent requirements for sustainable development? What industries are important for sustainable development? In what ways is sustainable development achieved?

To answer the three questions, based first on the coupling model, and then on the stability test of industrial integration and the industrial competitiveness index, and finally results of VAR and the Granger causality relation test, we found (1) the coupling degree ranged from 0.9 to 1 with minimal changes and that a strong coupling relationship existed between the electronic information industry and financial industry. The coupling coordination degree ranged between 0.59 and 0.80 , with a coordination level ranging from primary to intermediate coordination. The coordination degree after 2011 exceeded the level before the financial crisis, and reached a good coordination state in 2015, and has remained stable since then. (2) Since VAR is sensitive to the response of the lag period, the lag period can be selected according to the minimum criterion of the AIC and SC values. The lag period selected in this paper was two. (3) The premise of VAR and the Granger causality relation test is that the indicator data are stationary. The unit root test results for IC with a lag period of two showed that the IC was stable at the $1 \%, 5 \%$, and $10 \%$ significance levels; the unit root test results for IID with a lag period of two showed that the IID was stable at the $1 \%, 5 \%$, and $10 \%$ significance levels. (4) The integration of China's electronic information and financial industries have a positive impact on the competitiveness of the electronic information industry. When other conditions remained unchanged, if the IID increases by 1 unit, the IC increases by 0.125433 in lag phase 1 and 0.369962 in lag phase 2. (5) A unilateral causal relationship exists between industrial integration and industrial competitiveness; that is, industrial integration is the Granger cause of industrial competitiveness, but industrial competitiveness is not the Granger cause of industrial integration.

With the continuous advancement of Industry 4.0 [65] and Made in China 2025 [66], industrial integration has become an important process to promote industrial competitiveness. Industrial competitiveness, especially the competitiveness of the electronic information industry, plays an important role in enhancing China's overall national strength. First, as part of the economic power, industrial competitiveness will affect the strength between countries. In the information age, the electronic information industry and its products have entered various fields of international competition. Secondly, China has been in a turning point in social development, and its international influence has been continuously improved, but international friction and controversy have also increased. The reason is that the old order is loosening, and the new order has not yet formed. It is a good way to break through key areas and be far ahead of competitors, such as the development of 5G communication technology and artificial intelligence. Third, the industrial integration model of smart cities, big data, and cloud computing will help promote the network sharing, intensive integration, collaborative development, and efficient utilization of social production factors, which will significantly improve the economic operation level and efficiency. China's electronic information industry has established a relatively complete industrial system after undergoing a development process. However, when compared with foreign developed countries, there are still shortcomings such as a low level of integration, lack of core technology, and weak independent innovation. So, to promote the integration of the electronic information industry and further enhance the level of industrial competitiveness, we propose the following policy recommendations:

(1) In terms of government services, the Notice of the State Council on Printing and Distributing Certain Policies for Encouraging the Development of the Software Industry and the Integrated Circuit Industry was issued. The national science and technology major projects have created a good policy environment for the development of China's integrated circuit industry. We need to further improve government services in the future. First, we should further relax government regulations and various restrictions imposed on enterprises, promote the reform of mixed ownership of state-owned enterprises and further enhance the independent decision-making power of enterprises. If the government imposes 
various complicated and strict restrictions on enterprises, it will undoubtedly negatively affect the enthusiasm of entrepreneurs and the process of integration between industries. Second, it is necessary to encourage enterprises to improve the level of technological innovation, and accelerate the speed of industrial integration through the development of science and technology, so as to promote new industrial forms and improve industrial competitiveness. Finally, the government should pay attention to the system construction of intellectual property protection and fully protect the intellectual resources of the electronic information industry, so that enterprises have no worries in the process of investing in research and development.

(2) In terms of technology upgrades, technological innovation is the driving force for industrial integration. Technological innovation leads to technological integration, and the emergence of technological integration leads to changes in production technology. Then, technical barriers gradually disappear, blurring the boundaries of the industry, and the result is industrial integration. Therefore, industrial integration is based on technology integration, and technological innovation plays a catalytic role in the occurrence of industrial integration. China's electronic information industry has a low starting point and a weak technical foundation; the industry is far behind those of developed countries in terms of operating systems, chips, and integrated circuits. More recently, China has rapidly improved the development level of its information industry by introducing this foreign technology. However, while introducing technology, it did not pay attention to the digestion and innovation of technology, which has led to a serious shortage of core technologies in these industries, which has affected the sustainable development of the industry. Therefore, if China's electronic information industry tries to integrate with other industries, such as integration with the financial industry, it should consciously promote innovation of its own technology and promote the technology within industry integration, thereby gradually eliminating the technical barriers between industries.

(3) In terms of industry integration, first, we must pay attention to business integration and market integration. Business integration and market integration are essential prerequisites for the realization of industrial integration. Enterprises must constantly develop new products and open new markets to adapt to the development trend of industrial integration. Second, we must actively cultivate new formats that emerge during the process of industrial integration. Industrial penetration, industrial crossover, and industrial restructuring are three methods of industrial integration. The formation of these three methods will have new industrial forms, which are often the fastest-growing and most profitable sectors. Actively cultivating these new formats will play an important role in improving the efficiency of the electronic information industry and promoting the optimization and upgrading of the industrial structure. Finally, we must pay attention to the role of leading enterprises. Large-scale enterprises can promote the collaborative innovation of small and medium-sized enterprises, and strengthen the connection with small- and medium-sized enterprises, through the division of labor in the production chain to gain the comprehensive advantages of professional aggregation and diverse aggregation.

(4) In terms of effective capital access, a financial support system must be established to provide an investment and financing platform for the electronic information industry. First, bank loans can be used as the main financial channel to support the shortage of funds in the day-to-day operations of the electronic information industry. Second, insurance companies need to be encouraged to develop technology insurance for electronic information companies in the industries that need to take on huge investment risks and to ensure the supply of technology risk funds. Third, the government and other relevant departments can establish a securities investment insurance system. Through joint ventures of securities, insurance, and information technology companies, we can establish joint venture finance to provide strong support for the technical and financial needs of the electronic information industry. Finally, large- and medium-sized information technology enterprises must take effective measures in the development process, use all favorable conditions to attract venture capital, or establish joint venture investment funds to create a more diverse and scientific investment pattern. 
Finally, we answer the three questions. To answer the first question, improving industrial competitiveness is an inherent requirement for sustainable development. The low competitiveness of the industry indicates that the industry is not performing well in controlling costs, reducing resource consumption, and improving production efficiency. The improvement of industrial competitiveness shows that the industry performs better in these aspects. Only competitive enterprises or industries can gain an active position in the fierce market competition, thus creating conditions for sustainable development. To answer the second question, financial industry and electronic information industry are important for sustainable development. The financial industry is an industry with few environmental pollutions and is one of the representative industries of the modern high-end service industry. The development of the electronic information industry may have adverse effects on the environmental industry, such as water pollution and land pollution caused by heavy metal pollution, and may also have few adverse effects on the environment through industrial upgrading. Therefore, the development of these two industries is of great significance for sustainable development. To answer the third question, industrial integration is an important way to enhance industrial competitiveness and achieve sustainable development. Industrial integration can promote the efficient use of resources, break the inherent development model to solve the problem of insufficient coordination of industrial development, and achieve the optimization and upgrading of industrial structure.

Author Contributions: W.C. conceived and designed the research and methodology; Y.L. collected and compiled all of the data and literature; X.H. finished the calculation and analyzed the results; W.C. put forward the policies; Y.S. revised the manuscript and approved the manuscript; W.C. is responsible for future questions from readers as the corresponding author.

Funding: This paper was supported by the Chinese Academy of Social Sciences Foundation Project (2015YZD6), the National Nature Science Foundation Project (71263037), the Jiangxi Province Graduate Innovation Fund Project (YC2017-B005) and the Jiangxi Universities Humanities and Social Fund Project (GL1581). The authors are grateful for the support of the National Nature Science Foundation, National Social Science Foundation, and Nanchang University. The contents of this paper are solely the responsibility of the authors and do not represent the official views of the aforementioned institutes and funding agencies.

Conflicts of Interest: The authors declare no conflict of interest.

\section{References}

1. Holzer, C. China's economic culture: The ritual order of state and markets. China Inf. 2017, 31, $253-254$. [CrossRef]

2. Berta, M.; Bottero, M.; Ferretti, V. A mixed methods approach for the integration of urban design and economic evaluation: Industrial heritage and urban regeneration in China. Environ. Plan. B Urban Anal. City Sci. 2018, 45, 208-232. [CrossRef]

3. Jiayi, H. Integration and regional industrial development: Theoretical frameworks and literature reviews. J. China Int. Relat. 2018, 6, 1-28.

4. GSMA: Internet Value Chain-Interpreting Internet Development from the Perspective of Economics. Available online: https://wallstreetcn.com/articles/253131 (accessed on 11 February 2019).

5. China Electronic Information Industry Statistical Yearbook. Available online: http://nianjian.xiaze.com/ down/2018/zgxxcynj-2017.html (accessed on 5 January 2019).

6. Dang, H.; Gu, W.L.; Tang, J.M.; Van Asssche, A. Introduction to the special issue: China's changing integration into the global economy. China Econ. Rev. 2018, 47, 170-171. [CrossRef]

7. Robertson, P.E.; Sin, A. Measuring hard power: China's economic growth and military capacity. Def. Peace Econ. 2017, 28, 91-111. [CrossRef]

8. Walheer, B. How foreign investments contribute to economic growth of industrial parks in China: A production-frontier decomposition approach. Appl. Econ. Lett. 2019, 26, 281-285. [CrossRef]

9. Hitpass, B.; Astudillo, H. Editorial: Industry 4.0 challenges for business process management and electronic-commerce. J. Theor. Appl. Electron. Commer. Res. 2019, 14, 1-3. [CrossRef]

10. Gillet, R.; Hubner, G.; Plunus, S. Operational risk and reputation in the financial industry. J. Bank. Financ. 2010, 34, 224-235. [CrossRef] 
11. Barnett, M.L.; Salomon, R.M. Does it pay to be really good? Addressing the shape of the relationship between social and financial performance. Strateg. Manag. J. 2012, 33, 1304-1320. [CrossRef]

12. China Financial Yearbook. Available online: http://www.yearbookchina.com/navibooklist-n3018091411-19. html (accessed on 1 January 2019).

13. Fu, Y.; He, W.D.; Hao, R. Comparative analysis of financial industry competitiveness of regions in China. J. Sci. Ind. Res. 2019, 78, 11-14.

14. Kallioras, D.; Petrakos, G. Industrial growth, economic integration and structural change: Evidence from the EU new member-states regions. Ann. Reg. Sci. 2010, 45, 667-680. [CrossRef]

15. Chen, Y. Industrial information integration-A literature review 2006-2015. J. Ind. Inf. Integr. 2016, 2, 30-64. [CrossRef]

16. Latinovic, T.; Preradovic, D.; Barz, C.R.; Vadean, A.P.; Todic, M. Big data as the basis for the innovative development strategy of the industry 4.0. Int. Conf. Appl. Sci. 2019, 477, 012045. [CrossRef]

17. Rosenberg, N. Technological-change in the machine-tool industry, 1840-1910. J. Econ. Hist. 1963, $23,414-443$. [CrossRef]

18. Yoffie, D.B. Competing in the age of digital convergence. Calif. Manag. Rev. 1996, 3, 31-53. [CrossRef]

19. European Commission. Green Paper on the Convergence of Telecommunications, Media and Information Technology Sectors, and the Implications for Regulation. 1997. Available online: http://www.ispo.ece.be (accessed on 6 February 2019).

20. Uekusa, M. Some policy and regulatory issues in the Japanese electric power industry. In Electricity 21: Power Industry Technology and Management Strategies for the Twenty-First Century; OECD Publications and Information Centre: Washington, DC, USA, 1993; pp. 319-324.

21. Legewie, J. The political economy of industrial integration in ASEAN: The role of Japanese companies. J. Asia Pac. Econ. 2000, 3, 204-233. [CrossRef]

22. Steiner, M. Restructuring industrial areas: Lessons in support of regional convergence in an enlarging Europe. In Economic Convergence and Divergence in Europe: Growth and Regional Development in an Enlarged European Union; Edward Elgar Publishing: Cheltenham, UK, 2003; pp. 86-107.

23. Uson, S.; Valero, A.; Agudelo, A. Thermoeconomics and industrial symbiosis. Effect of by-product integration in cost assessment. Energy 2012, 45, 43-51. [CrossRef]

24. James, A.D.; Jun, H.C. Convergence in the information industries: Telecommunications, broadcasting, and data processing 1981-1996. In Progress in Communication Sciences; Ablex: Stamford, CT, USA, 1998; pp. 125-148.

25. Alfonso, G.; Salvatore, T. Does technological convergence imply convergence in markets? Evidence from the electronics. Ind. Res. Policy 1998, 27, 445-463.

26. Helleno, A.L.; Simon, A.T.; Papa, M.C.O.; Ceglio, W.E.; Neto, A.S.R.; Mourad, R.B.A. Integration university-industry: Laboratory model for learning lean manufacturing concepts in the academic and industrial environments. Int. J. Eng. Educ. 2013, 29, 1387-1399.

27. Jiang, Q.H. Industrial clusters, innovation and regional industrial brand: An example about Wenzhou industrial clusters of low-voltage electric. In Proceedings of the 2009 International Conference on Public Economics and Management, Xiamen, China, 28-29 November 2009; Volume 8, pp. 15-17.

28. Throsby, D. Assessing the impact of a cultural industry. J. Arts Manag. Law Soc. 2004, 34, 188-205. [CrossRef]

29. Cao, X.Q. Study on integration of informatization and industrialization characteristics and its interation relationship with industrial design. Front. Manuf. Sci. Meas. Technol. 2015, 5, 829-833.

30. Weick, K.E. Educational organizations as loosely coupled systems. Adm. Sci. Q. 1976, 21, 1-19. [CrossRef]

31. Chen, J. De-coupling of front-back stages in service industries: Developments from traditional operation to mass customization. Afr. J. Bus. Manag. 2011, 5, 11727-11735.

32. Su, Y.; Wang, F.Y.; An, X.L. Coupling mechanism and coupling degree measurement model of shipbuilding industry cluster. Pol. Marit. Res. 2016, 23, 78-85. [CrossRef]

33. Kim, N.; Lee, H.; Kim, W.; Lee, H.; Suh, J.H. dynamic patterns of industry convergence: Evidence from a large amount of unstructured data. Res. Policy 2015, 44, 1734-1748. [CrossRef]

34. Dosi, G. Finance, innovation and industrial-change. J. Econ. Behav. Organ. 1990, 13, 299-319. [CrossRef]

35. Banker, R.D.; Chang, H.H.; Majumdar, S.K. Economies of scope in the US telecommunications industry. Inf. Econ. Policy 1998, 10, 253-272. [CrossRef] 
36. Colombo, M.G.; Grilli, L. Access to bank loans by high-tech start-ups. Small Bus. Econ. 2007, $29,25-46$. [CrossRef]

37. Englmaier, F.; Reisinger, M. Information, coordination and the industrialization of countries. Econ. Stud. 2008, 54, 534-550. [CrossRef]

38. Saviotti, P.P.; Pyka, A. The co-evolution of technologies and financial institutions. In Recent Advances in Neo-Schumpeterian Economics: Essays in Honour of Horst Hanusch; Edward Elgar Publishing: Northampton, MA, USA, 2009; pp. 81-100.

39. Nelson, R.R. Economic growth via the co-evolution of technology and institutions. In Evolutionary Economics and Chaos Theory: New Directions in Technology Studies; Palgrave: New York, NY, USA, 1994; pp. 21-32.

40. Colombo, M.G.; Croce, A.; Grilli, L. ICT services and small businesses productivity gains: An analysis of the adoption of broadband internet technology. Inf. Econ. Policy 2013, 25, 171-189. [CrossRef]

41. Forero, M.D.B. Mobile communication networks and internet technologies as drivers of technical efficiency improvement. Inf. Econ. Policy 2013, 25, 126-141. [CrossRef]

42. Brock, W.A.; Xepapadeas, A.; Yannacopoulos, A.N. Spatial externalities and agglomeration in a competitive industry. J. Econ. Dyn. Control 2014, 42, 143-174. [CrossRef]

43. Anderson, J.O.; Toffolo, A. Improving energy efficiency of sawmill industrial sites by integration with pellet and CHP plants. Appl. Energy 2013, 111, 791-800. [CrossRef]

44. Oltean, F.D.; Gabor, M.R.; Contiu, L.C. Relation between information technology and performance: An empirical study concerning the hotel industry in Mures County. Emerg. Mark. Queries Financ. Bus. 2014, 15, 1535-1542. [CrossRef]

45. Lozada, M.C. Industry 4.0: The era of digitalization, generation and integration of industrial knowledge. Ingenius Rev. Cienc. Tecnol. 2019, 21, 7.

46. Nathan, A.J. Strategic coupling: East Asian industrial transformation in the new global economy. Foreign Aff. 2017, 96, 175.

47. Felicia, F.; Nicholas, V.T. Industry-specific competencies and converging technological systems: Evidence from patents. Struct. Chang. Econ. Dyn. 2001, 12, 141-170.

48. Pichler, A.; Steiner, K.; Fink, G.; Haiss, P. Financial integration in Europe: Effects on markets and economic growth. Serv. Lib. Intern. Mark. 2008, 6, 167-224.

49. Yuan, B.L.; Ren, S.G.; Chen, X.H. Can environmental regulation promote the coordinated development of economy and environment in China's manufacturing industry?-A panel data analysis of 28 sub-sectors. J. Clean. Prod. 2017, 149, 11-24. [CrossRef]

50. Hagedoorn, J.; Schakenraad, J. A comparison of private and subsidized research-and-development partnerships in the European information technology industry. J. Common Mark. Stud. 1993, 31, 373-390. [CrossRef]

51. Kastner, J.R.; Das, K.C. The potential of coupling biological and chemical/physical systems for air pollution control: A case study in the rendering industry. In Proceedings of the Air Pollution from Agricultural Operations III, Triangle Park, NC, USA, 12-15 October 2003; pp. 73-105.

52. Meyer, B.; Keller, F.; Wolfersdorf, C.; Lee, R.P. A concept for the circular carbon economy sector coupling of the energy, waste, and chemical industry. Chem. Ing. Tech. 2018, 90, 241-248. [CrossRef]

53. Warner, J.C.; Perlin, N.; Skyllingstad, E.D. Using the model coupling toolkit to couple earth system models. Environ. Model. Softw. 2008, 23, 1240-1249. [CrossRef]

54. Sakamoto, J. Industrial development and integration of underdeveloped countries. J. Common Mark. Stud. 1969, 7, 283-304. [CrossRef]

55. Zhao, L.M.; Li, L.; Wu, Y.J. Research on the coupling coordination of a sea-land system based on an integrated approach and new evaluation index system: A case study in Hainan Province, China. Sustainability 2017, 9, 5. [CrossRef]

56. Tanaka, H. Quantitative analysis of information security interdependency between industrial sectors. In Proceedings of the ESEM: 2009 3rd International Symposium on Empirical Software Engineering and Measurement, Lake Buena Vista, FL, USA, 15 October 2009; pp. 575-584.

57. Ataman, O.; Brian, S.; Victor, Z. Business cycles in the Euro Area defined with coincident economic indicators and predicted with leading economic indicators. J. Forecast. 2010, 29, 6-28.

58. Geert, D.; John, H. Technological convergence in the IT industry: The role of strategic technology alliances and technological competencies. Int. J. Econ. Bus. 1998, 5, 66-78. 
59. China Statistical Yearbook. Available online: http://www.stats.gov.cn/tjsj/ndsj/2018/indexch.htm (accessed on 6 January 2019).

60. China's Economic and Social Bigdata Platform. Available online: http://tongji.cnki.net/kns55/brief/result.aspx (accessed on 6 January 2019).

61. Lima, L.P.; Ribeiro, G.B.D.; Silva, C.A.B.; Perez, R. An analysis of the Brazilian dairy industry efficiency level. Int. Food Res. J. 2018, 25, 2478-2485.

62. Yakovenko, O.Z. Theoretical principles in formation of state industrial policy based on the development of industrial service clusters. Actual Probl. Econ. 2012, 136, 81-89.

63. Gochoco-Bautista, M.S.; Mapa, D.S. Linkages between trade and financial integration and output growth in East Asia. Asian Econ. J. 2010, 24, 1-22. [CrossRef]

64. Sims, C.A. Macroeconomics and reality. Econometrica 1980, 48, 1-48. [CrossRef]

65. Braccini, A.M.; Margherita, E.G. Exploring organizational sustainability of industry 4.0 under the triple bottom line: The case of a manufacturing company. Sustainability 2019, 11, 36. [CrossRef]

66. Yeung, G. Made in China 2025: The development of a new energy vehicle industry in China. Area Dev. Policy 2019, 4, 39-59. [CrossRef]

(C) 2019 by the authors. Licensee MDPI, Basel, Switzerland. This article is an open access article distributed under the terms and conditions of the Creative Commons Attribution (CC BY) license (http://creativecommons.org/licenses/by/4.0/). 